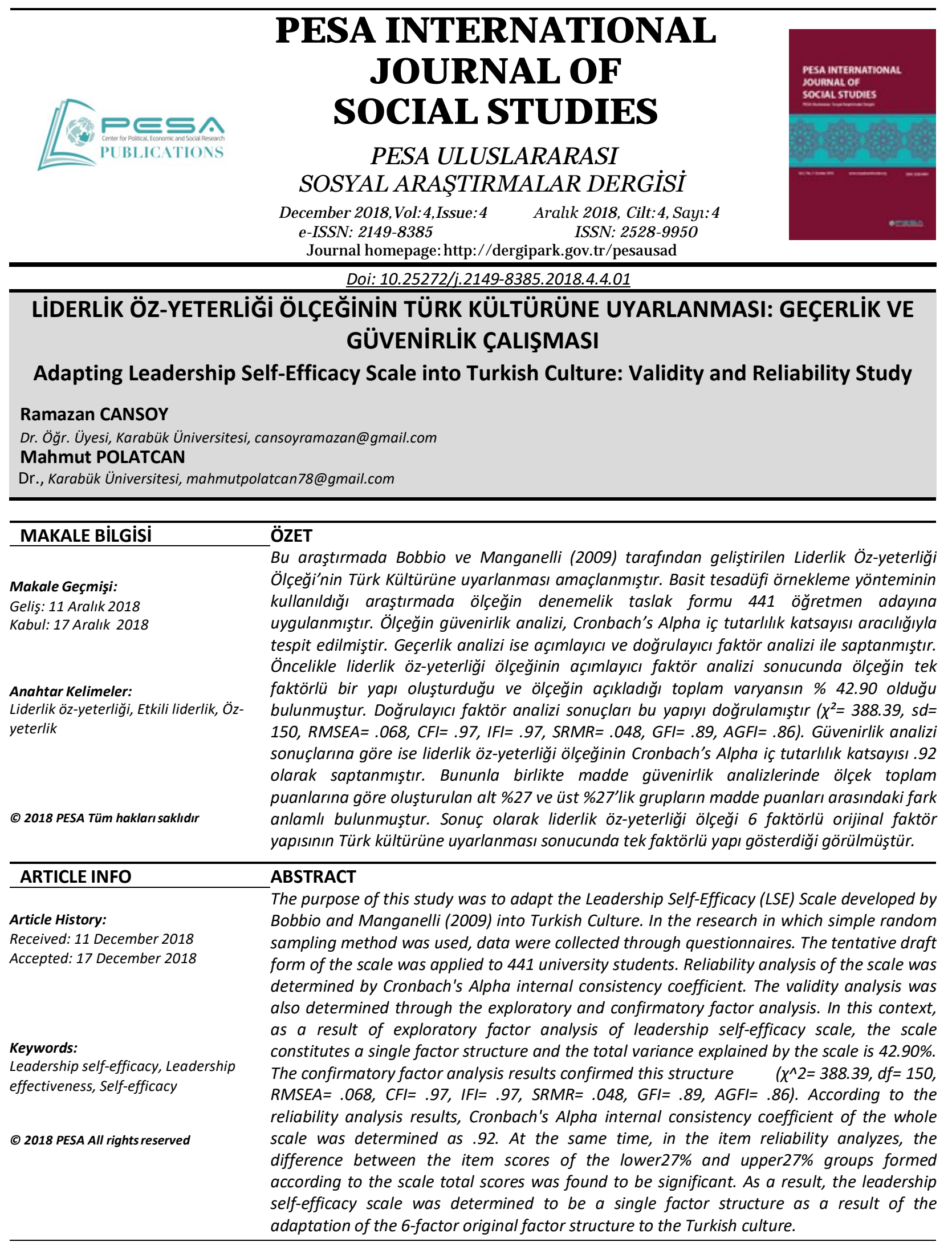

\title{
GiRiş
}

Bireyler çalışma yaşamında çeşitli engellerle karşılaşabilmektedirler. Öz-yeterliği yüksek olan bireyler zorluklara karşı direnç gösterebilen, baskı ve stres altında sağlıklı düşünebilen ve kolay güdülenebilen bireylerdir. Bireylerin öz-yeterliği kişisel başarı ya da başarısızlıklarla ilgili doğrudan deneyimlerinden, başkalarını izleyerek edindikleri dolaylı deneyimlerden, fizyolojik ve duygusal durumlardan etkilenmektedir. Bireylerin başarılı deneyimleri, bir işi başarabilme ve üstesinden gelebilme inancını artırmaktadır. Bunun yanında bireylerin çevresindekilerin başarılı deneyimlerini modellemeleri, bir 
görevde yetkin olduklarına dair teşvik edilmeleri de öz-yeterlik inancını artırmaktadır (Bandura, 1986; 1997).

Öz-yeterlik bireyin belirli bir görevi yerine getirebilmesine ilişkin kendine olan inancı ve yaşamını kontrol edebilme kapasitesi olarak ifade edilmektedir (Bandura, 1997; 2006). Bireylerin engellerle başa çıkabilmek için gösterdikleri çaba ve dayanıklııkları bireylerin öz-yeterlikleri ile ilgilidir (Bandura, 1997; Zimmerman, 1995). Bununla birlikte öz-yeterlik bireyin istenilen amaçlara ulaşmak için görevlerini başarıyla yerine getirebilme çabası, kendisine olan güveni ve performansını düzenleyebilmesidir (Gist ve Mitchell, 1992; Maurer, 2001; Stajkovic ve Luthans, 1998). O halde özyeterlik bireysel amaçları gerçekleştirmede, zorluklar ve engellerin üstesinden gelmede, başarılı bir performans ortaya koymada içsel bir kaynak olarak ifade edilebilir.

Öz-yeterlik algılarının farklı görevleri yerine getirmeye yönelik yeterlikler bağlamında incelendiği görülmektedir. Bu alanlara teknoloji kullanımına yönelik öz-yeterlik, öğretmen öz-yeterliği ve bir dersin öğretimine yönelik öz-yeterlik örnek verilebilir. Bu bağlamda son yıllarda göreve yönelik özyeterlik davranışları çerçevesinde liderlik öz-yeterliği kavramının dikkat çekmeye başladığı görülmektedir (McCormick, Tanguma ve López-Forment, 2002; Paglis ve Green, 2002; Ng, Ang ve Chan, 2008). Bunun yanında liderlik öz-yeterliğinin bireysel ve örgütsel değişkenlerle olumlu yönde ilişkilerinin tespit edilmesi, kavramı daha iyi anlamaya yönelik çalışmaların yapılması gerektiğini düşündürmektedir. Bu çalışmalardan Stajkovic ve Luthans (1998), bireylerin öz-yeterlik algılarının liderlik performanslarını etkilediğini, Paglis ve Green (2002) ise yöneticilerin liderlik öz-yeterlik algılarının örgütsel değişim sürecinde oluşabilecek sorunların çözümü için bireysel motivasyonun bir kaynağı olduğunu belirtmektedirler. Bununla birlikte öz-yeterlik çıktıları açısından da ele alınmaktadır. Nitekim bir dizi araştırmada bireylerin öz yeterlilik algılarının bireylerin yaptıkları işlerde başarıları ve motivasyonları ile ilişkili olduğu tespit edilmiştir (Bandura, 2006; Ng, Ang ve Chan, 2008; Stajkovic ve Luthans, 1998). Bu kapsamda Bandura (1997) bireysel öz-yeterlik inancının akademik başarıyı, kariyer seçimini, girişimciliği, karar vermeyi, örgütsel işleyişi, stresle başa çıkmayı ve öğretim performansını etkilediğini ileri sürmektedir.

Liderlik öz-yeterliğinin incelenmesi örgütlerin çıktılarını etkilemede hayati bir özellik olarak görülen liderlik davranışlarının kaynaklarının anlaşımasında ve liderlik ile ilgili yetkinlik inancının geliştirilmesinde bazı faydalı bulgular sunabilir. Bu ifadeleri destekleyecek biçimde Paglis, (2010) liderliğin daha iyi anlaşılabilmesine yönelik liderlik davranışlarının liderlik öz-yeterlik inancı bağlamında değerlendirilmesi gerektiği ifade etmiştir. Bu ifadelerden hareketle liderlik öz-yeterliğinin incelenmesini sağlayacak ölçme araçlarının geliştirilmesinin liderlik davranışlarının kaynaklarının anlaşılması bakımından önemli olduğu söylenebilir.

\section{Liderlik Öz-yeterliği}

Liderlik örgüt çalışanlarının şu anda nerede olduğunu ve gelecekte nerede olması gerektiğini belirlemek için strateji oluşturmayı gerektiren bir süreçtir. Ayrıca liderlik takipçilerini etkilemeyi ve takipçilere örgütteki değişimi sağlamaya yönelik birlikte çalışma prensibi kazandırmayı gerektirmektedir (Paglis ve Green, 2002). Örgütlerde etkili liderlik pozitif iklim ve güven oluşturmaktadır. Dolayısıyla örgütte etkili liderlik için öz-yeterlik önemlidir (Hannah, Avolio, Luthans ve Harms, 2008). Bu kapsamda liderlik öz-yeterliği, liderlikle farklı kavramlar arasında ilişkilerin incelendiği araştırmaların sonucunda ortaya çıkmıştır. Liderlik öz-yeterliği, örgütsel bağlılık (Paglis ve Green, 2002) ve performans düzeyi arasındaki ilişkilerin incelenmesi, kavramın teorik alt yapısının oluşmasında etkili olmuştur (Luthans ve Peterson, 2002). Bobbio ve Manganelli (2009) bireylerin liderlik öz-yeterliklerini gruplarda değişim süreçlerinin öncüsü olabilme, etkili takipçi oluşturabilme, etkili iletişim kurabilme, başkalarını motive edebilme ve özgüven sahibi olma olarak değerlendirmişlerdir. Liderlik öz-yeterliği, liderlerin bir çalışma grubunun yönünü belirlemeye yönelik inançları olarak ifade edilmektedir (Paglis ve Green, 2002; McCormick, Tanguma ve López-Forment, 2002). Liderlik öz-yeterliği, bireyin liderlik rollerini etkili bir şekilde gerçekleştirebilmesi ve hedeflenen görevleri yerine getirmek için sahip olduğu bireysel yeteneklere ilişkin algılarının bir bütünüdür $(\mathrm{Ng}$, Ang ve Chan, 2008). Bununla birlikte liderlik öz-yeterliği yöneticinin değişime liderlik eden kişisel uzmanlık deneyimleriyle ilgilidir (Machida ve Schaubroeck, 2011). O halde liderlik öz-yeterliği bireyleri bir amaç etrafında toplayabilme, yönlendirebilme ve ortak amaçları gerçekleştirebilmek için kişilerin 
kendileri ile ilgili yetkinlik inancını ifade eder yorumu yapılabilir.

Liderlik öz-yeterliği bireylerin liderlikle ilgili davranışlarını sergileyebilme inancını ifade etmektedir ( $\mathrm{Ng}$, Ang ve Chan, 2008). Nitekim göreve özgü liderlik öz-yeterliğine sahip bireyler daha fazla sorumluluk üstlenen, çaba harcayan, zorluklar karşısında daha uzun süre ısrarcı davranan kişilik özellikleri sergilemektedirler (Paglis ve Green, 2002). Bunların yanında Paglis ve Green'e (2002) göre, liderlik öz-yeterliği güçlü yöneticilerin yön belirleme, bağlılı̆ı arttırma ve örgütte değişim konusunda astlarına yönelik daha çok girişimde bulunduklarını ifade etmektedirler. Kane, Zaccaro, Tremble ve Masuda (2002), liderlik öz-yeterliğine sahip yöneticilerin yüksek hedefler koyduklarını ve daha iyi bir grup stratejisine sahip olduklarını göstermişlerdir. Ng, Ang ve Chan (2008), iş özerkliğine bağılı olarak liderlik öz-yeterliliğinin duygusal dengesizlik, dışadönüklük ve vicdanlıık arasındaki ilişkilere aracılık ettiğini saptamışlardır.

Liderlik öz-yeterliği ile ilişkileri olduğu bilinen bazı değiş̧enlerden bahsedilmektedir. Çalışma ortamında liderlik öz-yeterliğini etkileme potansiyeli taşıyan bazı öncüller bulunmaktadır (Paglis ve Green, 2002). Bunlar kişisel başarıma yönelik deneyimler, iç kontrol odağı yönelimi, yüksek öz-benlik algısı, astlara güven, yöneticilerin olumlu davranışlarını modelleme, koçluk desteği, performans geri bildirimi ve örgütteki destekleyici davranışlardır (Anderson, Krajewski, Goffin ve Jackson, 2008; Bobbio ve Manganelli, 2009; McCormick, 2001; Paglis ve Green, 2002; Prussia, Anderson ve Manz, 1998). Bunların yanında yöneticilerin değişime açıklıkları, örgütlerde esnek çalışma ortamlarının tesis edilmesi ve özgün davranışların desteklendiği çalışma ortamlarının oluşturulması, yönetimde özerkliğin teşvik edilmesi liderlik öz-yeterliğini etkileyebilmektedir (Bobbio ve Manganelli, 2009; Leithwood ve Jantzi, 2008; McCormick, 2001; Paglis ve Green, 2002). Bu bağlamda bireylerin liderlik öz-yeterlik gelişimlerinde Bandura'nın (1997) öz-yeterlik kaynakları bağlamında ele aldıkları kişisel deneyimler, sözel destek, dolaylı yaşantıların önemli olduğu görülebilir.

Liderlik öz-yeterliğinin farklı özellikler çerçevesinde tartışıldığı ve bireylerdeki liderlik öz-yeterliği niteliklerinin ortaya konulmasına yönelik boyutlandırma çalışmaları olduğu görülmektedir. Bunlardan Paglis ve Green (2002) yöneticilerin değişim liderliğine yönelik motivasyonlarına odaklandığı çalışmalarında liderlik öz-yeterliğini üç özellik altında ifade etmişlerdir. Bunlar gruba yön belirlemek, takipçilerin değişim hedefleri konusunda bağlılığını arttırmak ve değişimin önündeki engelleri kaldırmaktır. Kane ve Baltes (1998) ise, liderlik öz-yeterlik özelliklerini farklı ortamlarda lider olarak iyi bir performans sergilemek, grup üyelerini motive etmek, grup üyelerinin güvenini sağlamak, takım çalışmasını geliştirmek, gerektiğinde risk almak, etkili iletişim kurmak, etkili görev stratejileri geliştirmek ve grubun güçlü ve zayıf yönlerini değerlendirmek olarak ele almışlardır.

Yukarıda ifade edildiği gibi araştırmacılar liderlik öz-yeterliğini incelemeye yönelik girişimlerde bulunmuşlardır. Benzer biçimde, Bobbio ve Manganelli (2009) liderlik öz-yeterliği kapsamında altı boyutlu bir ölçme aracı geliştirmişlerdir. Bu bağlamda bu çalışmada Bobbio ve Manganelli (2009) tarafından geliştirilen Liderlik Öz-yeterlikleri Ölçeğinin Türk kültürüne uyarlanması hedeflenmiştir. Bu ölçeğin boyutları ve özellikleri şunlardır:

Değişim süreçlerini başlatmak ve yönetmek, grup için yeni bir yön belirleyebilme, gruptakilerin tutumlarını değiştirebilme, kontrolü kısmen de olsa sağlayabilmeyi ifade eder.

Etkili takipçiler seçme ve sorumluluk vermek, etkili grup oluşturabilme, grup içinde iş dağılımı yapabilme, grup üyelerine hedeflere yönelik çalışmalara yönlendirebilme, uygun kişilere görev verebilmeyi ifade eder.

Kişilerarası ilişkiler kurmak ve yönetmek, gruptakilerle iyi ilişkiler kurabilmeyi, gruptakilerle sağlıklı iletişi kurabilmeyi ifade eder.

Öz-farkındalık ve özgüven sahibi olmak, güçlü ve zayıf yönlerini tespit edebilmeyi, kişisel başarıya olan inancı, içinde bulunduğu şartları olumluya çevirmeyi, deneyimleriyle grup üyelerine danışmanlık ve rehberlik yapabilmeyi, inanç ve değerlerini çalışanlara aktarabilmeyi ifade eder.

Motive etmek, gruptakilere model olabilmeyi, bir işle ilgili gruptakileri güdüleyebilmeyi ve onlara firsatlar sunabilmeyi ifade eder.

Üyeler arasında fikir birliğini sağlamak, yaptıklarıyla çalışanların takdirini kazanabilmeyi, grupta 
ortak fikir oluşturabilmeyi ve kendisini gruptakilere lider kabul ettirebilmeyi ifade etmektedir.

Ulusal alanyazında bireylerin farklı görevleri yerine getirebilmelerine yönelik öz-yeterliklerini ortaya koyan çok sayıda araştırma olmasına rağmen liderlik öz yeterliklerine ilişkin bir ölçme aracına rastlanamamıştır. Bu bakımdan bu çalışmayla liderlik çalışmalarına bir destek verilmesi ve alanyazının genişletilmesi hedeflenmektedir. Geliştirilen bu ölçme aracının uygulanması ile bireylerin liderlik yapabilme inançlarına ilişkin yetkinlikleri ortaya konabilir. Diğer taraftan liderlik eğitimine yönelik programların etkililiğinin tespit edilmesinde faydalı bir ölçme aracı olabilir. Bunun yanında liderlik özyeterliğinin farklı bireysel ve örgütsel değişkenlerle ilişkileri araştırılarak alan yazındaki liderlik özyeterliği kavramının daha iyi anlaşıması sağlanabilir. Bu bağlamda bu araştırmada eğitim alanında bireylerin liderlik öz-yeterliğini ölçebilecek geçerli ve güvenilir bir ölçme aracının Türk kültürüne uyarlanması amaçlanmıştır.

\section{Yöntem}

\section{Çalışma Grubu}

Ölçek uyarlama çalışması, araştırmanın bağlamına uygun olarak yükseköğretim öğrencilerinden oluşmaktadır. Basit tesadüfi örnekleme yönteminin kullanıldığı araştırmada veriler uyarlanmak istenen ölçek aracılığıyla toplanmıştır. Araştırmanın verileri formasyon programına devam eden 441 öğretmen adayından elde edilmiştir. Katılımcıların 321'i kadın (\%72), 112'si (\%28) erkektir. Katılımcıların yaşları 19 ile 36 arasında değişmektedir.

\section{Veri Toplama Aracı}

\section{Çok Boyutlu Liderlik Öz Yeterliği Ölçeği}

Bireylerin liderlik öz-yeterliklerini değerlendirmek amacıyla Bobbio ve Manganelli (2009) tarafından geliştirilen Çok Boyutlu Liderlik Öz Yeterliği Ölçeği (ÇBLÖY) üniversite öğrencileri ve yetişkinler üzerinde iki kez uygulanan ve 21 madde ve altı alt boyuttan oluşan Likert tipinde yedili (1)kesinlikle katılmıyorum ile (7) kesinlikle katılıyorum arasında derecelendirilen bir ölçektir. Liderlik öz-yeterliği ölçeğinden alınan yüksek puanlar arttıkça, liderlik davranışlarını gösterebilmeye yönelik kendilerine ilişkin inançlarının güçlendiğini göstermektedir. Orijinal ölçek formu; gruplarda değişim süreçlerini başlatma ve yönetme ( 3 madde), etkili takipçiler seçme ve sorumluluk verme (4 madde), grup içerisinde kişilerarası ilişkiler kurma ve yönetme ( 3 madde), öz-farkındalık ve özgüven sahibi olma (5 madde), motive etme ( 3 madde) ve grup üyeleri arasında fikir birliği sağlama ( 3 madde) boyutlarından oluşmaktadır.

Bobbio ve Manganelli (2009) liderlik öz-yeterliği ölçeğinin yapı geçerliği için yapılan Açımlayıcı Faktör Analizi sonucunda; öğrenci grubu örnekleminde ölçeğin yapı geçerliği için faktör yükleri gruplarda değişim süreçlerini başlatmak ve yönetmek alt boyutu için .70 ile .78; etkili takipçiler seçme ve sorumluluk verme alt boyutu için .61 ile .68; grup içerisinde kişilerarası ilişkiler kurma ve yönetme alt boyutu için .46 ile .69; öz-farkındalık ve özgüven sahibi olma alt boyutu .42 ile .63; motive etme alt boyutu için .56 ile .67; grup üyeleri arasında fikir birliği sağlama alt boyutu için .54 ile .69 ve tüm maddeler için .42 ile .78 aralıklarında bulunmuştur. Yetişkin grubu örnekleminde ölçeğin yapı geçerliği için faktör yükleri gruplarda değişim süreçlerini başlatmak ve yönetmek alt boyutu için .68 ile .76; etkili takipçiler seçme ve sorumluluk verme alt boyutu için .66 ile .73; grup içerisinde kişilerarası ilişkiler kurma ve yönetme alt boyutu için .52 ile .71; öz-farkındalık ve özgüven sahibi olma alt boyutu .48 ile .74; motive etme alt boyutu için .60 ile .76; grup üyeleri arasında fikir birliği sağlama alt boyutu için .56 ile .79 ve tüm maddeler için .50 ile .79 aralıklarında tespit edilmiştir. Üniversite öğrencileri üzerinde uygulanan ölçeğin güvenirliğe ait iç tutarlılık katsayıları ölçek boyutları için .63 ile .77 arasında bulunmuştur. Tüm ölçek için ise .91 olarak bulunmuştur. Yetişkinler üzerinde test edilen ölçeğin boyutlarına ilişkin iç tutarlılık katsayıları .65 ile .79 arasında bulunmuştur. Ölçeğin maddelerinin tamamının güvenirlik katsayısı $\alpha=.94$ olarak bulunmuştur (Bobbio ve Manganelli, 2009).

\section{Verilerin Analizi}

Liderlik öz-yeterliği ölçeğinin maddelerinin ölçtükleri özellikleri güvenilir olarak ölçmelerine ilişkin Cronbach's Alpha iç tutarlılık katsayısı kullanılarak tüm ölçek maddelerinin ve alt faktörlerinin 
güvenirlik katsayıları belirlenmiştir. Ölçeğin maddelerinin hangi boyutlarda kümelendiğini görmek amacıyla Açımlayıcı Faktör Analizi (AFA) yapılmıştır. Katılımcılardan elde edilen verilerin faktör yapılarının doğrulanıp doğrulanmadığını belirlemek için Doğrulayıcı Faktör Analizi (DFA) yapılmıştır. DFA, önceden belirlenmiş faktörlerin verilerle uyumlu olup olmadığını test etmek amacıyla ve ölçme araçlarının yapı geçerliliğini belirlemek amacıyla kullanılan güçlü bir istatistiksel tekniktir. DFA ölçme aracının orijinal yapısına ilişkin modelin uyum indekslerinin doğrulanmadığı durumlarda açıklayıcı faktör analizi aracılığıyla hedeflenen kültürün faktör yapısının keşfedilmesine başvurulabilir (Çokluk, Şekercioğlu ve Büyüköztürk, 2010).

\section{İşlem}

Çok boyutlu liderlik öz yeterliği ölçeğinin uyarlanması sürecinde öncelikle ölçeği geliştiren Bobbio ve Manganelli ile e-posta aracılığıyla iletişim kurulmuş ve ilgili araştırmacılardan gerekli izinler alınmıştır. Daha sonra ilk olarak ölçeğin İngilizce formu araştırmacılar tarafından Türkçeye çevrilmiştir. İkinci aşamada Türkçeye çevrilen ölçek formu iki uzman tarafından tekrar İngilizceye çevrilmiş ve formlar arasındaki tutarlılıklar değerlendirilmiştir. Son aşamada oluşturulan denemelik ölçek formu, eğitim yönetimi ve ölçme değerlendirme uzmanı üç uzman akademisyen tarafından incelenmiş ve uzman görüşleri doğrultusunda ölçeğin nihai hali oluşturulmuştur. Nitekim Büyüköztürk'ün (2011) belirttiği gibi ölçme aracının kapsam geçerliğinin incelemede başvurulabilecek yöntemlerden biri de uzman görüşlerini almaktır. Ölçme aracının kapsam geçerliği, liderlik öz-yeterliği kavramının maddelerinin içeriğe uyumlu olup olmadığını ortaya koymaktadır. Öte yandan ölçeğin yapı geçerliği iççn AFA analizi ve DFA uygulanmıştır. Ölçeğin güvenirliği için iç tutarlıık katsayılarına, madde analizi için düzeltilmiş madde toplam korelasyonuna bakılmıştır. Ölçeğin geçerlik analizi için LISREL ve güvenirlik analizleri için ise SPSS paket programları kullanılmıştır.

\section{Bulgular}

Bu kısımda uyarlanan ölçeğin madde analizleri yapı geçerliği ve güvenirlik analizi aracılığıyla yapılmıştır.

\section{Yapı Geçerliği}

Açımlayıcı Faktör Analizi. AFA temel bileşenler analizi Varimax dik döndürme tekniği öncesi Örneklem büyüklüğünün geçerliğini test etmek için yapılan işlem sonrasında Kaiser-Meyer-Olkin (KMO)=.93 değerinin, Bartlett's Sphericity testinin ve Ki-Kare değerinin $(X 2=3926.01 ; p=0.00)$ anlamlı olduğu, verilerin faktör analizi için uygun olduğu tespit edilmiştir. 21 maddeden oluşan liderlik öz-yeterliği ölçeğinin AFA analizi sonucunda orijinal formda olduğu gibi öz değeri 1.00'den büyük 4 alt boyuttan oluştuğu saptanmasına karşın, ölçek maddelerinin kendi boyutları altında toplanmadığı görülmüştür. Döndürme öncesi oluşan alt boyutlar varyansın \%58.90'ını açıklamaktadır. Ancak ölçeğin madde faktör yük değerleri .30'un altında olan 6. ve 17. maddeler ölçekten çıkarılmış ve 19 madde üzerinden analize devam edilmiştir. Temel bileşenler analizi ile yapılan AFA sonucunda ölçeğin Türk kültüründe tek alt boyut oluşturduğu belirlenmiştir. Açımlayıcı faktör analizi sonucunda liderlik öz-yeterliği ölçeğinin faktör yükleri ve açıklamış olduğu toplam varyans tablo 1'de verilmiştir.

Tablo 1. Liderlik öz-yeterliği için AFA'dan elde edilen madde faktör yük değerleri

\begin{tabular}{cccc}
\hline Madde No & Faktör Yükleri & Madde No & Faktör Yükleri \\
\hline M16 & .78 & M5 & .63 \\
M18 & .76 & M13 & .61 \\
M14 & .74 & M11 & .59 \\
M12 & .74 & M4 & .59 \\
M15 & .71 & M2 & .57 \\
M20 & .71 & M7 & .57 \\
M9 & .71 & M1 & .54 \\
\hline
\end{tabular}




\begin{tabular}{llcc}
$\mathrm{M} 21$ & .68 & $\mathrm{M} 3$ & .52 \\
$\mathrm{M} 19$ & .66 & $\mathrm{M} 10$ & .51 \\
$\mathrm{M} 8$ & .64 & & \\
\hline
\end{tabular}

Açıklanan Toplam Varyans $\quad \% 42.90$

Tablo 1 incelendiğinde, ölçeğin faktör yük değerlerinin ise .42-.78 arasında değiştiği gözlenmektedir. Bununla birlikte ölçeğin tek başına açıklamış olduğu toplam varyans \%42.90'dır. Buna göre faktör yük değerlerinin liderlik öz-yeterliği ile orta ve yüksek düzeyde ilişkili olduğu ifade edilebilir.

Analiz sonucunda elde edilen tek alt boyutun öz değeri 8.235 ve açıkladığı varyans \%42.40'tür. Sosyal bilimler alanında yapılan çalışmalarda toplam varyansın \% 40 ile \% 60 arasında olmasının ölçeğin faktör yapısının güçlü olduğunu göstermektedir (Tavşancıl, 2002). Orijinal ölçeğin 6 boyutlu olmasına karşın, Türk kültürüne uyarlama çalışmaları sonucunda, maddelerin tek alt boyutta toplandığı gözlenmiştir. Dolayısıyla tek boyutlu yapı alanyazın ve veri analizi çerçevesinde yeniden adlandııılmış uzman görüşü de alınarak, bu tek boyut "liderlik öz-yeterliği" olarak ifade edilmiştir. AFA sonucu elde edilen faktörleşme grafiği şekil 1'de verilmiştir.

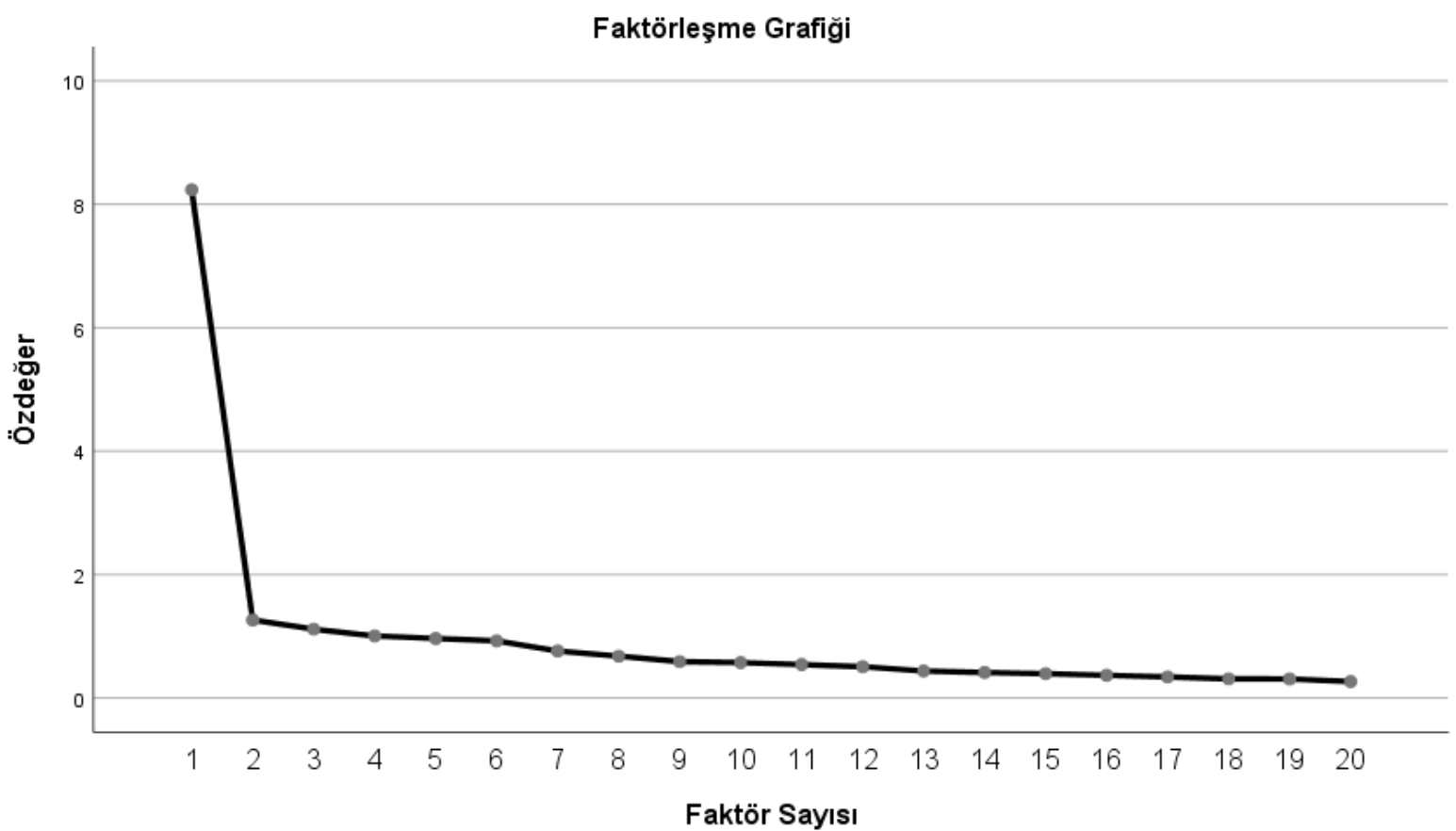

Şekil 1. AFA sonucu elde edilen faktörleşme grafiği

Doğrulayıcı Faktör Analizi. Liderlik öz-yeterliği ölçeğinin AFA sonucu ortaya çıkan tek boyutlu yapısının geçerliğini belirlemek için DFA uygulanmıştır. Uygulanan DFA sonucunda ki-kare $\left(\chi^{2}\right)$ uyumu serbestlik derecesi (sd) oranı, artık ortalamaların karekökü (RMR), yaklaşık hataların ortalama karekökü (RMSEA), karşılaştırmalı uyum indeksi (CFI), standardize edilmiş artık ortalamaların karekökü (SRMR), iyilik uyum indeksi (GFI), düzenlenmiş iyilik uyum indeksi (AGFI) gibi uyum değerleri incelenmiştir (Çokluk, Şekercioğlu ve Büyüköztürk, 2010; Hu ve Bentler, 1999). DFA'ya yönelik uyum kabul değerleri tablo 2'de verilmiştir.

Tablo 2. Doğrulayıcı Faktör Analizi Uyum İndeksleri Kabul Değerleri

\begin{tabular}{lllc}
\hline $\begin{array}{l}\text { Uyum } \\
\text { Indeksi }\end{array}$ & Ölçütler & $\begin{array}{l}\text { Kabul Edilebilir Uyum } \\
\text { Değerleri }\end{array}$ & DFA \\
\hline$\chi^{2}$ & $p>0,05$ & - & 388,39 \\
& & & $(s d=150, p=0,00)$ \\
\hline
\end{tabular}


R.CANSOY, M.POLATCAN / Liderlik Öz-Yeterliği Ölçeğinin Türk Kültürüne Uyarlanması: Geçerlik Ve Güvenirlik Çalışması

\begin{tabular}{|c|c|c|c|}
\hline$\chi^{2} / s d$ & - & $\leq 3=$ mükemmel uyum & 2,58 \\
\hline RMSEA & $\begin{array}{l}\text { O(mükemmel uyum) } \\
1 \text { (uyum yok) }\end{array}$ & $\begin{array}{l}\leq 0,05=\text { mükemmel uyum } \\
\leq 0,08=\text { iyi uyum }\end{array}$ & 0,068 \\
\hline SRMR & $\begin{array}{l}\text { O(mükemmel uyum) } \\
1 \text { (uyum yok) }\end{array}$ & $\leq 0,08=$ iyi uyum & 0.048 \\
\hline $\mathrm{CFI}$ & $\begin{array}{l}\text { O(uyum yok) } \\
1 \text { (mükemmel uyum) }\end{array}$ & $\geq 0,90=$ iyi uyum & 0.97 \\
\hline IFI & $\begin{array}{l}\text { O(uyum yok) } \\
1 \text { (mükemmel uyum) }\end{array}$ & $\geq 0,90=$ iyi uyum & 0.97 \\
\hline $\mathrm{GFI}$ & $\begin{array}{l}\text { O(uyum yok) } \\
1 \text { (mükemmel uyum) }\end{array}$ & $\geq 0,90=$ iyi uyum & 0.89 \\
\hline AGFI & $\begin{array}{l}0 \text { (uyum yok) } \\
1 \text { (mükemmel uyum) }\end{array}$ & $\geq 0,90=$ iyi uyum & 0.86 \\
\hline
\end{tabular}

Kaynak: Çokluk, Ö., Şekercioğlu, G. ve Büyüköztürk, Ş. (2010). Sosyal bilimler için çok değişkenli istatistik: SPSS ve LISREL uygulamaları. Ankara: Pegem Akademi, s.271-272'den alınmıştır.

Doğrulayıcı faktör analizi sonucunda ölçeğin uyum indeksleri $\left(\chi^{2}=38.39, s d=150, R M S E A=.068, C F I=\right.$ $.97, I F I=.97, S R M R=.048, G F I=.89, A G F I=.86)$ iyi uyum verdiğini ortaya koymuştur. Sonuç olarak bu araştırmada, Bobbio ve Manganelli (2009) tarafından geliştirilen Liderlik Öz-yeterlikleri Ölçeğinin DFA analizi sonucunda modelin tek faktörlü olarak iyi uyum verdiği göstermiştir. Ölçek maddelerine ilişkin DFA sonuçları şekil 2'de verilmiştir.

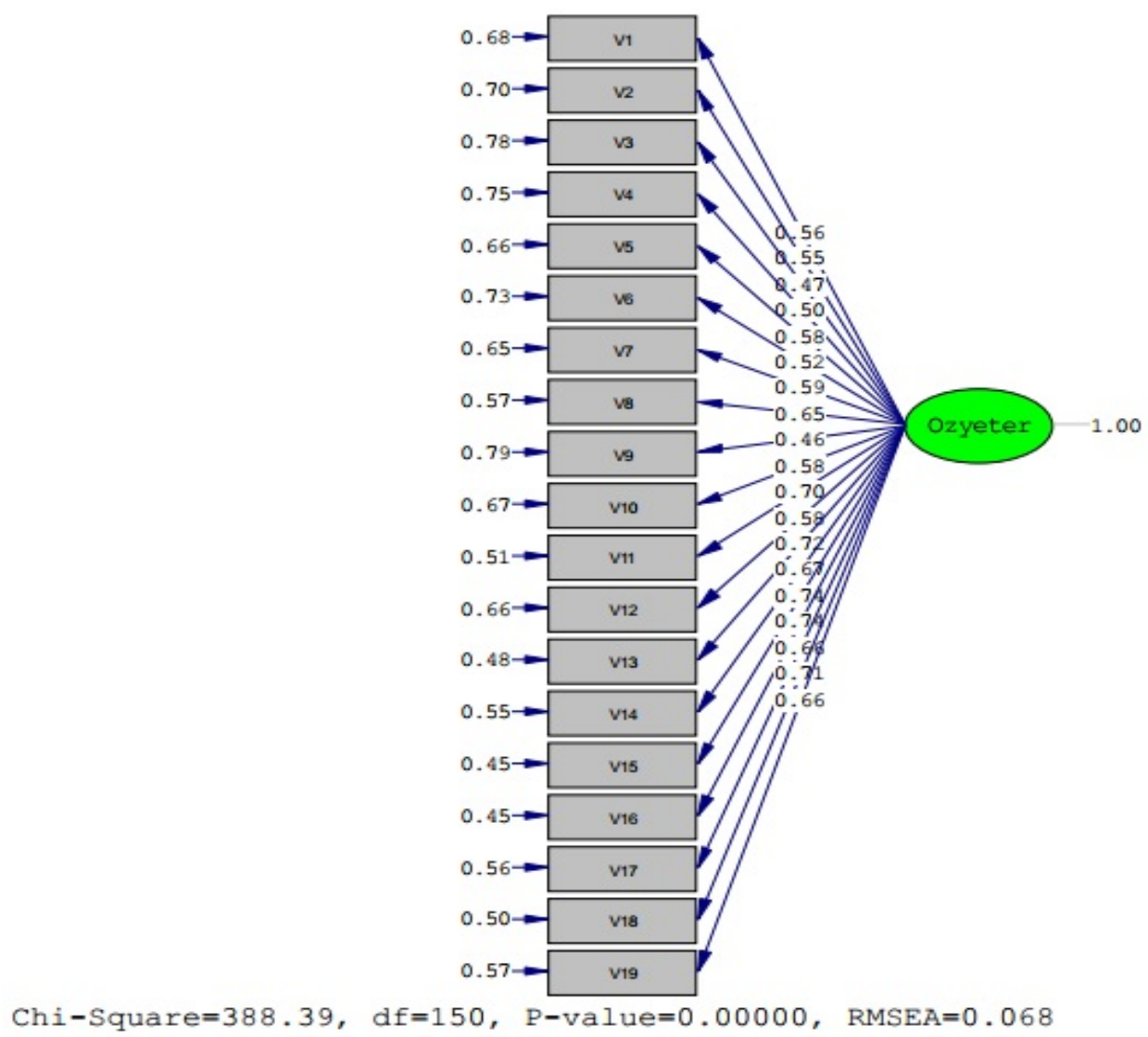

Şekil 2. Ölçeğe illişkin Doğrulayıcı Faktör Analizi Sonuçları

Şekil 2'deki madde faktör yükleri ve uyum indeksleri dikkate alındığında, ölçeğin Türkçe formunun ölçeğin tek boyutlu formuyla bazı uyum indekslerinde (CFI, IFI) mükemmel uyum verdiği bazı uyum indekslerinde ise (GFI, AGFI) kabul edilebilir düzeyde uyum gösterdiği söylenebilir.

\section{Güvenirlik Analizi}

Liderlik öz-yeterliği ölçeğinin maddelerinin ayırt ediciliğini belirlemek amacıyla Cronbach Alpha 
güvenirlik katsayısına ve düzeltilmiş madde toplam korelasyonlarına bakılmıştır. Ölçeğin düzeltilmiş madde korelasyonları tablo 2'de verilmiştir.

Tablo 2. Liderlik Öz-yeterliği Ölçeğinin Madde Toplam Korelasyonları

\begin{tabular}{|c|c|c|}
\hline Madde No & Madde Toplam Korelasyonu & Güvenirlik $(\alpha)$ \\
\hline M1 & .49 & \\
\hline $\mathrm{M} 2$ & .53 & \\
\hline M3 & .48 & \\
\hline M4 & .54 & \\
\hline M5 & .58 & \\
\hline M7 & .52 & \\
\hline M8 & .59 & \\
\hline M9 & .66 & .92 \\
\hline M10 & .45 & \\
\hline M11 & .54 & \\
\hline M12 & .69 & \\
\hline M13 & .55 & \\
\hline M14 & .69 & \\
\hline M15 & .66 & \\
\hline M16 & .73 & \\
\hline M18 & .71 & \\
\hline M19 & .61 & \\
\hline M20 & .67 & \\
\hline M21 & .62 & \\
\hline
\end{tabular}

Tablo 2'ye göre liderlik öz-yeterliği ölçeği maddelerinin güvenirliği için düzeltilmiş madde toplam korelasyonlarına bakılmış ve ölçek maddelerinin madde korelasyonları .45-.73 arasında değiştiği görülmüştür. Ölçeğin tüm maddeleri için güvenirlik katsayısı $\alpha=.92$ olarak hesaplanmıştır.

Madde güvenirlik analizlerinde ölçek toplam puanlarına göre oluşturulan alt \%27 ve üst \%27'lik gurupların madde puanları arasındaki farkların hesaplanması yöntemidir. Gruplar arasındaki farkların anlamlı olması ölçeğin iç tutarlılığının bir göstergesi olarak kabul edilmektedir (Büyüköztürk, 2011). Liderlik Öz-yeterliği Ölçeği Puanının \%27'lik Alt ve Üst Gruplara ilişkin farkın anlamlılığı tablo 3’te verilmiştir.

Tablo 3. Liderlik Öz-yeterliği Ölçeği Puanının \%27'lik Alt ve Üst Gruplara ilişkin t-Testi Sonuçları

\begin{tabular}{|c|c|c|c|c|c|c|}
\hline & Gruplar & $\mathbf{N}$ & Ortalama & $S$ & $\mathbf{t}$ & p \\
\hline \multirow{2}{*}{$\begin{array}{l}\text { Liderlik Öz- } \\
\text { yeterliği }\end{array}$} & Alt & 120 & 4.62 & .98 & 10.759 & .00 \\
\hline & Üst & 120 & 5.58 & .70 & & \\
\hline
\end{tabular}

Tablo 3'e göre ölçekte yer alan alt \%27 ve üst \%27'lik gruplar arasındaki fakların anlamlı olduğu görülmektedir ( $p<.05 ; t=10.759$ ). Bu bağlamda liderlik öz-yeterliği ölçeğinin maddelerin bireylerin davranışlarının iyi bir ayırt edicisi olduğu ifade edilebilir.

\section{Sonuç ve Tartışma}

Bu çalışmada Liderlik öz-yeterliği ölçeğinin uyarlaması kapsamında ölçek maddelerinin özgün dilden 
Türkçeye çevrilmesi ve elde edilen Türkçe ölçek formunun geçerlik ve güvenirliği hesaplanmıştır. Uzman görüşleri doğrultusunda dilsel eşdeğerliliği belirlenen Türkçe formunun geçerlik ve güvenirlik çalışması 441 üniversite öğrencisi üzerinde gerçekleştirilmiştir. Geçerlik çalışması kapsamında Türkçe formun Türk kültüründeki yapısını değerlendirebilmek amacıyla yapı geçerliği DFA ile yapılmıştır. DFA uyum indeksleri dikkate alındığında, modelin iyi uyum verdiği ve ölçeğin altı boyutlu orijinal faktör yapısının (Hu ve Bentler, 1999) Türk kültürüne uyarlama çalışmaları sonucunda tek boyutlu bir faktör yapısı gösterdiği görülmüştür.

Liderlik öz-yeterliği faktör analizi sonucunda oluşan tek faktörlü yapının faktör yük değerleri .42 ile .78 arasında değiştiği görülmüş̧ür. Ölçeğin açıklamış olduğu toplam varyans yaklaşık olarak $43^{\prime}$ tür. Tek faktörlü ölçeğin güvenirliğine yönelik olarak bakılan Cronbach Alpha güvenirlik katsayısının $\alpha=.92$ olduğu ve düzeltilmiş madde toplam korelasyonlarının .45 ile .73 arasında değiştiği görülmüştür. Bununla birlikte ölçeğin güvenirliğine ilişkin yapılan alt \%27 ve üst \%27'lik gurupların madde puanları arasındaki farkların anlamlı olduğu saptanmıştır. Bu bilgiler ışığında ölçeğin uygun yapı ve güvenirlik değerlerine sahip olduğu şeklinde yorumlanabilir.

Ölçeğin Türk dili ve kültürüne uyarlanması sonucu altı boyut yerine tek boyut çıktığı görülmüştür. Bunun bazı nedenleri olabilir. Öncelikle tüm maddeler bireylerin kendileri hakkında olumlu ifadelere yer vermektedir. Diğer taraftan orijinal ölçeğin geliştirildiği ülke ile Türk kültürü arasındaki farklııklar buna neden olmuş olabilir.

Sonuç olarak yapılan analizler bağlamında Liderlik Öz-yeterliği Ölçeğinin Türk kültüründe bireylerin liderlik öz-yeterlik düzeylerinin belirlenmesinde kullanılabilecek geçerli ve güvenilir bir ölçme aracı olduğu söylenebilir. Ölçeğin uyarlama çalışmasının üniversitedeki öğretmen adayları üzerinde gerçekleştirildiğinden öğretmen ve okul yöneticileri gibi farklı örneklemler üzerinde incelenerek ölçeğin standartlaştırılması önerilebilir. Bununla birlikte ölçeğin ölçüt geçerliğini belirlemek amacıyla, geçerlik ve güvenirliği saptanmış benzer ölçme araçları arasındaki ilişkiler incelenebilir.

\section{Kaynakça}

Anderson, D. W., Krajewski, H. T., Goffin, R. D., \& Jackson, D. N. (2008). A leadership self-efficacy taxonomy and its relation to effective leadership. The Leadership Quarterly, 19(5), 595-608.

Bandura, A. (2006). Guide for constructing self-efficacy scales. Self-efficacy Beliefs of Adolescents, 5(1), 307-337.

Bandura, A. (1997). Self-efficacy: The exercise of control. New York: Freeman.

Bandura, A. (1986). The explanatory and predictive scope of self-efficacy theory. Journal of Social and Clinical Psychology, 4(3), 359-373.

Bobbio, A., \& Manganellii, A. M. (2009). Leadership self-efficacy scale: A new multidimensional instrument. TPM-Testing, Psychometrics, Methodology in Applied Psychology, 16(1), 3-24.

Büyüköztürk, Ş. (2011). Sosyal bilimler için veri analizi el kitabı. Ankara: Pegem Akademi.

Çokluk, Ö., Şekercioğlu, G., \& Büyüköztürk, Ş. (2010). Sosyal bilimler için çok değişkenli istatistik: SPSS ve LISREL uygulamaları. Ankara: Pegem Akademi.

Gist, M. E., \& Mitchell, T. R. (1992). Self-efficacy: A theoretical analysis of its determinants and malleability. Academy of Management Review, 17(2), 183-211.

Hannah, S. T., Avolio, B. J., Luthans, F., \& Harms, P. D. (2008). Leadership efficacy: Review and future directions. The Leadership Quarterly, 19(6), 669-692.

Hu, L. T., \& Bentler, P. M. (1999). Cut off criteria for fit indexes in covariance structure analysis: Conventional criteria versus new alternatives. Structural Equation Modeling: $A$ Multidisciplinary Journal, 6(1), 1-55.

Kane, T. D., Zaccaro, S. J., Tremble Jr, T. R., \& Masuda, A. D. (2002). An examination of the leader's regulation of groups. Small Group Research, 33(1), 65-120.

Kane, T. D., \& Baltes, T. R. (1998). Efficacy assessment in complex social domains: Leadership efficacy 
in small task groups. Paper presented at the annual meeting of The Society of Industrial and Organizational Psychology. Dallas, TX.

Leithwood, K., \& Jantzi, D. (2008). Linking leadership to student learning: The contributions of leader efficacy. Educational Administration Quarterly, 44(4), 496-528.

Luthans, F., \& Peterson, S. J. (2002). Employee engagement and manager self-efficacy. Journal of Management Development, 21(5), 376-387.

Machida, M., \& Schaubroeck, J. (2011). The role of self-efficacy beliefs in leader development. Journal of Leadership \& Organizational Studies, 18(4), 459-468.

Maurer, T.J. (2001). Career-relevant learning and development, worker age, and beliefs about selfefficacy for development. Journal of Management, 27, 123-140.

McCormick, M. J., Tanguma, J., \& López-Forment, A. S. (2002). Extending self-efficacy theory to leadership: A review and empirical test. Journal of Leadership Education, 1(2), 34-49.

McCormick, M. J. (2001). Self-efficacy and leadership effectiveness: Applying social cognitive theory to leadership. Journal of Leadership Studies, 8(1), 22-33.

Ng, K. Y., Ang, S., \& Chan, K. Y. (2008). Personality and leader effectiveness: a moderated mediation model of leadership self-efficacy, job demands, and job autonomy. Journal of Applied Psychology, 93(4), 733.

Paglis, L. L. (2010). Leadership self-efficacy: Research findings and practical applications. Journal of Management Development, 29(9), 771-782.

Paglis, L. \& Green, S. (2002). Leadership self-efficacy and managers' motivation for leading change. Journal of Organizational Behavior, 23(2), 215-235. doi: 10.1002/job.137

Prussia, G. E., Anderson, J. S., \& Manz, C. C. (1998). Self-leadership and performance outcomes: The mediating influence of self-efficacy. Journal of Organizational Behavior,19(5), 523-538.

Stajkovic, A. D., \& Luthans, F. (1998). Social cognitive theory and self-efficacy: Goin beyond traditional motivational and behavioral approaches. Organizational Dynamics, 26(4), 62-74.

Tavşancıl, E. (2002). Tutumların Ölçülmesi ve SPSS ile Veri Analizi. Ankara: Nobel Akademi.

Zimmerman, B. J. (1995). Self-efficacy and educational development. Self-Efficacy in Changing Societies, 202-231. doi:10.1017/cbo9780511527692.009

\section{EXTENTED ABSTRACT}

\section{Purpose}

The concept of self-efficacy, described effective individuals as people who are motivated, resilient to adversity, goal-oriented, and able to think clearly even under pressure or in stressing condition. In literature is moreover that leadership roles are generally assumed by people with high self-efficacy beliefs who are inclined to expend greater efforts to fulfill their leadership roles and to persevere longer when faced with difficulties (Bandura, 1997). Leadership Self-efficacy refers to the belief in competence of oneself to consolidate and motive the individuals for an aim and to carry out the common aims. Leadership self-efficacy, defined as a person's judgment that he or she can successfully exert leadership by setting a direction for the work group, building a relationship with followers in order to gain their commitment to change goals, and working with them to overcome obstacles to change (Paglis and Green, 2002). Leadership self-efficacy consists of the dimensions of starting and leading change processes in groups, choosing effective followers and delegating responsibilities, Building and managing interpersonal relationship within the group, showing selfawareness and self-confidence, motivating people, gaining consensus of group members (Bobbio and Manganelli, 2009). The purpose of this study was to adapt the Leadership Self-Efficacy (LSE) Scale developed by Bobbio and Manganelli (2009) into Turkish culture. 


\section{Method}

This research is the work of a scale adaptation. The population of this study was composed of the students in the Karabuk University, and the sample of the study was composed of 441 university students. Leadership self-efficacy validity study, confirmatory factor analysis was conducted in order to prove the structural validity of the scale. The internal consistency coefficient was calculated in a reliability study. SPSS 22.00 and Lisrel 8.80 programs were used for the analysis of the data. In the study, first translation process applied. After that, two academicians agreed on the latest Turkish form of the scale. Lastly, Turkish form was applied.

\section{Results}

In this study, Confirmatory Factor Analysis were performed. As a result of the Confirmatory Factor Analysis, the path diagram and the goodness-of-fit criteria were obtained and these findings were interpreted. As a result of the data analysis, for the models tried to be confirmed, $\chi 2 / d f$, RMSEA and $\mathrm{CFI}, \mathrm{GFI}$ and AGFI were used as the statistical fitness criteria. Reliability analysis of the scale was determined by Cronbach's Alpha internal consistency coefficient. The reliability analysis of the scale was determined through Cronbach's Alpha internal consistency coefficient. The validity analysis was also determined through the confirmatory factor analysis. As a result, the confirmatory factor analysis results implemented to determine the construct validity of the one-dimensional self-efficacy scale $\quad\left(\chi^{2}=388.39, d f=150, R M S E A=.068, C F I=.97, I F I=.97, S R M R=.048, G F I=.89, A G F I=.86\right)$. According to the reliability analysis results, item correlations corrected for each item of the Leadership Self-Efficacy Scale were found between .45 and .73, and Cronbach's Alpha internal consistency coefficient of the whole scale was determined as .92. At the same time, in the item reliability analyzes, the difference between the item scores of the lower $27 \%$ and upper $27 \%$ groups formed according to the scale total scores was found to be significant. As a result, leadership selfefficacy scale one factor structure was determined to be compatible with factor structure adapted into Turkish culture.

\section{Conclusion}

In this study, it was aimed to develop a valid and reliable scale with the aim of determining the attitudes leadership self-efficacy of university students. For this purpose, firstly, a scale of 21 items was prepared; then, it was administered to 441 participants having seen an audit; finally, the obtained data was analyzed. As a result, within the frame of this study, it was found that the leadership self efficacy scale that was adapted to Turkish culture is a reliable and valid scale which can be used to determine the leadership self-efficacy of primary education teachers.

\section{LIDERLiK ÖZYETERLiĞi ÖLÇEĞi}

Kesinlikle

Katılmıyorum

Kesinlikle

Katılıyorum

1 Bir grupla çalışırken gerektiğinde yeniden bir yön belirleyebilirim.

2 Bir grupla çalışırken herkesin kabul edebileceği ortak bir hedef belirleyebilirim.

3 Bir grupla çalışırken grubu etkileyerek bazı değişiklikler yapıımasını sağlayabilirim.

$4 \quad$ Etkili bir grup oluşturmak gruba nitelikli bireylerin seçimini sağlayabilirim.

$\begin{array}{lllllll}1 & 2 & 3 & 4 & 5 & 6 & 7\end{array}$

$\begin{array}{lllllll}1 & 2 & 3 & 4 & 5 & 6 & 7\end{array}$

$\begin{array}{lllllll}1 & 2 & 3 & 4 & 5 & 6 & 7\end{array}$

$\begin{array}{lllllll}1 & 2 & 3 & 4 & 5 & 6 & 7\end{array}$

5 Etkili sonuçlara ulaşmak için grup üyeleri arasında iş dağııımını en iyi biçimde yapabilirim.

6 Grupta kime görev verilecek rahatlıkla anlayabilirim.

$\begin{array}{lllllll}1 & 2 & 3 & 4 & 5 & 6 & 7\end{array}$

$\begin{array}{lllllll}1 & 2 & 3 & 4 & 5 & 6 & 7\end{array}$

7 Genellikle birlikte çalıştığım kişilerle iyi ilişkiler kurabilirim.

$\begin{array}{lllllll}1 & 2 & 3 & 4 & 5 & 6 & 7\end{array}$

8 Başkalarıyla bir konuyla ilgili açık ve anlaşılır iletişim kurabilirim.

$\begin{array}{lllllll}1 & 2 & 3 & 4 & 5 & 6 & 7\end{array}$

9 Bir gruptaki herkesle düzeyli ilişkiler kurabilirim.

\begin{tabular}{lllllll}
1 & 2 & 3 & 4 & 5 & 6 & 7 \\
\hline
\end{tabular}


10 Güçlü ve zayıf yönlerimi anlayabilirim.

$\begin{array}{lllllll}1 & 2 & 3 & 4 & 5 & 6 & 7\end{array}$

11 Bir işi başaracağıma inanırım.

$\begin{array}{lllllll}1 & 2 & 3 & 4 & 5 & 6 & 7\end{array}$

12 Zor durumda kalsam bile bu durumu fırsata dönüştürebilirim.

$\begin{array}{lllllll}1 & 2 & 3 & 4 & 5 & 6 & 7\end{array}$

13 Bir grup çalışmasında başkalarına yardımcı olacak kadar $\begin{array}{lllllll}1 & 2 & 3 & 4 & 5 & 6 & 7\end{array}$ deneyimim ve yeteneğim olduğuna inanıyorum.

14 Liderlik pozisyonu elde edersem kendi inanç ve değerlerimi $\begin{array}{lllllll}1 & 2 & 3 & 4 & 5 & 6 & 7\end{array}$ anlaşılır ve açık olarak ifade edebilirim.

15 Bir gruptakileri rol-model davranışlarımla motive edebilirim. $\begin{array}{lllllll}1 & 2 & 3 & 4 & 5 & 6 & 7\end{array}$

16 Bir gruptakiler işlerini yaparlarken motive olmalarına yönelik $\begin{array}{lllllll}1 & 2 & 3 & 4 & 5 & 6 & 7\end{array}$ davranışlar sergileyebilirim.

17 Benimle iş yapanlar genellikle yaptığım işlerden dolayı beni takdir $\quad \begin{array}{llllllll}1 & 2 & 3 & 4 & 5 & 6 & 7\end{array}$ ederler.

18 Grup üyeleri arasında fikir birliği sağlayabileceğimden eminim. $\begin{array}{lllllll}1 & 2 & 3 & 4 & 5 & 6 & 7\end{array}$

19 Bir grup çalışmasında genellikle lider olarak beni seçerler.

$\begin{array}{lllllll}1 & 2 & 3 & 4 & 5 & 6 & 7\end{array}$

Not: Ölçek kaynak gösterilerek kullanılabilir. 